УДК 343.9

DOI https://doi.org/10.32837/npnuola.v28i29.721

\author{
О. В. Дроздова, К. Г. Заріцька
}

\title{
СЛІДЧИЙ СУДДЯ ЯК ГАРАНТ ЗАБЕЗПЕЧЕННЯ ЗАКОННОСТІ ТА ОБІРУНТОВАНОСТІ ОБМЕЖЕННЯ КОНСТИТУЦІЙНИХ ПРАВ І СВОБОД ЛЮДИНИ ПІД ЧАС ПРОВЕДЕННЯ НЕГЛАСНИХ СЛІДЧИХ (РОЗШУКОВИХ) ДІЙ
}

Постановка проблеми. 3 прийняттям Кримінального процесуального кодексу України (далі - КПК України) в Україні запроваджено інститути негласних слідчих (розшукових) дій (далі - НС(Р)Д) та судового контролю за дотриманням прав, свобод та інтересів осіб у кримінальному провадженні на стадії досудового розслідування. Враховуючи той факт, що в судовій практиці часто трапляються випадки, коли основними доказами у кримінальному провадженні є саме результати, отримані від проведення НС(Р)Д, дотримання процесуального порядку їх здійснення та правильність ї оформлення часто впливає на допустимість їх як доказів.

Метою статті $€$ розкрити роль та особливості здійснення слідчим суддею судового контролю за дотриманням прав людини під час проведення НС(Р)Д.

Виклад основного матеріалу. Не викликає сумніву той факт, що забезпечення судового контролю слідчими суддями за проведенням НС(Р) Д відіграє неабияке значення у процесі проведення досудового розслідування, оскільки вони часто пов'язані з обгрунтованим втручанням у приватне життя осіб, тимчасовим обмеженням конституційних прав і свобод громадян.

Відповідно до статті 12 Загальної декларації прав людини «ніхто не може зазнавати безпідставного втручання у його особисте й сімейне життя, безпідставного посягання на недоторканність його житла, тайну його кореспонденції або на його честь і репутацію»[1]. У статті 8 Конвенції про захист прав людини і основоположних свобод зазначено, що «кожен має право на повагу до свого приватного і сімейного життя, до свого житла і кореспонденції» [2]. Ці положення знаходять своє відбиття і в Конституції України, зокрема: кожному гарантується недоторканість житла (стаття 30), таємниця листування, телефонних розмов, телеграфної та іншої кореспонденції (стаття 31), не втручання в його особисте і сімейне життя (стаття 32) [3]. Як міжнародні договори, так і Конституція України гарантують забезпечення цих прав за винятком випадків, коли 
втручання здійснюється згідно із законом з метою запобігання злочинам чи з'ясування істини під час розслідування кримінальної справи, якщо іншими способами одержати інформацію неможливо.

Відповідно до чинного КПК України якщо відомості про кримінальне правопорушення та особу, яка його вчинила, неможливо отримати в інший спосіб у кримінальних провадженнях щодо тяжких або особливо тяжких злочинів, слідчі під час досудового розслідування уповноважені проводити НС(Р)Д. Рішення про проведення НС(Р)Д приймає слідчий, прокурор, а в окремих випадках слідчий суддя за клопотанням прокурора або за клопотанням слідчого, погодженого 3 прокурором [4]. Звідси випливає, що для проведення НС(Р)Д суб'єкти їх проведення повинні мати законні підстави (юридичні та фактичні), що є гарантією дотримання законності в ї проведенні, і подальше використання результатів проведених НC(Р) Д у доказуванні [5, с. 305]. Конфіденційний характер НС(Р)Д об’єктивно зумовлює виникнення проблеми підтвердження достовірності отриманих у їх результаті відомостей, їх оцінки з погляду належності та допустимості та, як наслідок, обгрунтування легітимності використання як доказів у кримінальному провадженні [6].

Відповідно до КПК України на підставі ухвали слідчого судді проводяться такі НС(Р)Д як: втручання у приватне спілкування (статті 260, $261,263,264)$, обстеження публічно недоступних місць, житла чи іншого володіння особи (стаття 267) установлення місцезнаходження радіоелектронного засобу (стаття 268), спостереження за особою, річчю або місцем (стаття 269), аудіо-, відеоконтроль місця (стаття 270), негласне отримання зразків, необхідних для порівняльного дослідження (стаття 274) [4].

Слідчий суддя уповноважений здійснювати судовий контроль і забезпечувати законність і обгрунтованість обмеження конституційних прав і свобод людини на стадії досудового слідства в кримінальному провадженні (прийняття рішення про застосування заходів кримінально-процесуального примусу, надання дозволу на проведення слідчих та інших процесуальних дій, що обмежують конституційні права людини) [4]. Для такої діяльності слідчого судді притаманні інституційна автономність, незалежність, незаінтересованість у результатах провадження, особиста відповідальність, усебічне й неупереджене дослідження й оцінка отриманих доказів [7, с. 14].

У цілому судовий контроль у сучасній юридичній літературі визнається самостійною організаційно-правовою формою реалізації судової влади [8, с. 367], системою передбачених кримінально-процесуальним законом засобів, спрямованих на реалізацію конституційних функцій судової влади, покликаних, у кінцевому підсумку, до недопущення незаконного та необгрунтованого обмеження прав особистості у кримінальному процесі, до іiі поновлення у цих правах або можливої їх компенсації засобами права [9, с. 220], законодавчо регламентованою, непреюдиціальною діяльністю, що здійснюється за наявності процесуальної підстави у визначених межах спеціальним суб'єктом - слідчим суддею з метою перевірки дотримання прав, свобод та інтересів осіб у кримінальному провадженні» Такий судовий контроль є засобом обмеження свавілля з боку держави (державних органів і посадових осіб), у зв'язку із чим застосування будь-якого 
державного примусового заходу процесуального характеру поза судовим рішенням є неприпустимим[10, с. 452].

Судовий контроль здійснюється за трьома процесуальними формами:

1) ухвалення рішення про застосування до обвинуваченого (підозрюваного) заходів забезпечення кримінального провадження;

2) розгляду скарг учасників досудового розслідування на рішення, дії чи бездіяльність слідчого чи прокурора;

3) надання дозволу на здійснення НС(Р)Д [11, с. 144].

Судовий контроль слідчим суддею під час проведення НС(Р)Д здійснюється не за додержанням законів під час проведення досудового розслідування (це конституційний обов'язок (функція) прокурора), а лише за дотриманням прав людини під час здійснення кримінальної процесуальної діяльності владними суб’єктами кримінального провадження - слідчим і прокурором.

Судовий контроль за дотриманням прав людини під час проведення НС(Р)Д вирізняється своєю специфікою, яку зумовлюють такі ознаки:

а)це суворо регламентована законом кримінально-процесуальна діяльність, сутність якої полягає у перевірці й оцінюванні законності та обгрунтованості певних дій і (або) рішень органів та осіб, які здійснюють досудове розслідування, а також у вирішенні питання про допустимість обмеження певних прав і свобод конкретної особи;

б) суб'єктом контролю виступає лише слідчий суддя;

в)метою контролю є захист конституційних прав, свобод і законних інтересів громадян;

г) судовий контроль виступає для громадян гарантією законності діяльності органів і осіб, які здійснюють досудове розслідування;

г) ця діяльність не пов'язана із вирішенням питання про винуватість особи, яка притягується до кримінальної відповідальності;

д) такий вид контролю здійснюється виключно на стадії досудового розслідування;

е) результатом цього контролю є внесення загальнообов'язкового, забезпеченого примусовою силою держави судового акта (ухвали);

є) межі судового контролю зводяться до таких основних вимог: він не повинен перетворюватися на управління розслідуванням; за його здійснення неприпустиме порушення прав та основоположних свобод людини $[12$, с. 44-45].

Звичайно, слідчий суддя є досить новітньої процесуальною фігурою для кримінального судочинства України, який здійснює свої повноваження саме на досудовому провадженні, у тому числі, щодо реалізації такої функції як судовий контроль. Введення такого суб’єкту у кримінальний процес слід розглядати як процесуальний інститут, що спрямований на створення додаткових гарантій для учасників кримінального провадження $[13$, с. 184$]$.

Особливістю діяльності слідчого-судді є те, що під час здійснення судового контролю за дотриманням прав, свобод та законних інтересів осіб не вирішує питання про винність або невинуватість особи, притягнутої до кримінальної відповідальності, а здійснює перевірку правомірності застосуван- 
ня до осіб заходів процесуального примусу, які обмежують конституційний принцип недоторканності особи [9, с. 20], а також запобігає неправомірним діям і рішенням, що порушують конституційні права і свободи громадян.

Нині до основних проблем правового регулювання судового контролю слідчих суддів під час проведення НС(Р)Д слід віднести:

1) невизначеність чіткого розуміння у нормах кримінального процесуального закону статусу втручання у приватне спілкування у системі $\mathrm{HC}(\mathrm{P})$ Д: як самостійної НС(Р)Д, яка може проводитись у визначених законом різновидах, чи узагальнюючого поняття, що містить у собі чотири самостійні НС(Р)Д, визначені нормами КПК України як різновиди втручання у приватне спілкування [14];

2) невизначеність і відсутність чітких меж судового контролю, зокрема в разі задоволення клопотання та надання дозволу на проведення НС(Р)Д слідчий суддя безпосередньо не здійснює подальшого контролю чи нагляду за ї виконанням, не отримує від слідчого чи прокурора повідомлення про результати їх проведення [15, с. 279];

3) невизначеність правового статусу та повноважень слідчого судді, оскільки в КПК України не передбачено жодної статті, яка б окремо регламентувала повноваження слідчого судді навіть у загальному характері, що призводить до того, що повноваження слідчого судді досить обширні та різнопланові [16];

4) невизначеність і відсутність чіткого порядку відбору кандидатів на виконання судово-контрольної функції [17, с. 325].

Враховуючи ступінь втручання у права людини, вимоги законодавства і обмежувальні критерії, що висуваються до цього виду отримання інформації, під час розгляду клопотань про надання дозволу на проведення негласних заходів слідчими суддями, з урахуванням вимог законодавства, застосовується певний алгоритм, тобто послідовність перевірки інформації, наданої слідчим, прокурором на відповідність вимогам закону і фактичним обставинам справи [18].

Відповідно до статті 238 КПК України слідчий суддя зобов'язаний розглянути клопотання про надання дозволу на проведення НС(Р)Д протягом 6 годин з моменту його отримання і ухвалити рішення відповідно до загальних вимог досудових рішень, тобто таке рішення повинно бути законним, обгрунтованим і вмотивованим [4]. А звідси випливає, що слідчий суддя повинен здійснювати судовий контроль під час проведення НС(Р)Д шляхом перевірки поданих сторонами доказів обгрунтованості клопотання про здійснення НС(Р)Д, доказів (матеріалів), отриманих за результатами НС(Р)Д. Наприклад, виходячи зі змісту частини 2 статті 248 КПК України під час задоволення клопотання на проведення НС(Р)Д, слідчий суддя має переконатися в повноті даних, наведених у такому документі. Водночас варто звернути увагу й на те, що слідчий суддя має враховувати специфіку дії та ту обставину, що в певних випадках неможливо вказати всі відомості, передбачені частиною 2 статті 248 КПК України [19, с. 22]. Однак жодна НС(Р)Д не може бути проведена за відсутності певного кола передбачених законом підстав, від наявності яких залежить законність та обгрунтованість рішення щодо провадження НСРД i, як наслідок, 
допустимість одержаних за такої умови доказів [20, с. 121]. Під час ухвалення слідчим суддею рішення про дозвіл на проведення НСРД, такий суддя має переконатися, що його рішення є законним, тобто ухвалене згідно 3 нормами матеріального права 3 дотриманням вимог щодо кримінального провадження; обгрунтованим, тобто ухвалене судом на підставі об'єктивно з'ясованих обставин, які підтверджені доказами, дослідженими під час судового розгляду та оціненими судом відповідно до статті 94 КПК України; вмотивовані, тобто є рішенням, в якому наведені належні і достатні мотиви та підстави його ухвалення [4].

Відповідно до пункту 2.4 Інструкції про НС(Р)Д прокурором вивчаються матеріали кримінального правопорушення, які $є$ підставою для прийняття рішення про погодження клопотання слідчого про надання дозволу на проведення НС(Р)Д, водночас під час ухвалення рішення слідчим суддею про надання дозволу на проведення НС(Р)Д не встановлено обов'язок досліджувати такі матеріали кримінального провадження, лише право вимагати такі матеріали для підтвердження необхідності проведення НС(Р)Д [21]. На думку О.В. Соколова, під час прийняття Інструкції про НС(Р)Д Генеральна прокуратура України, Міністерство внутрішніх справ України, Служба безпеки України, Адміністрація державної прикордонної служби України, Міністерство фінансів України, Міністерство юстиції України, передбачивши не обов'язок, а право слідчого судді досліджувати матеріали кримінального провадження, які підтверджують необхідність проведення НС(Р) Д, віднесли вказані повноваження до зони дискреції суду [22, с. 36], що $€$ сукупність прав та обов'язків суб'єкта на власний розсуд визначати повністю або частково вид і зміст управлінського рішення, можливість вибору на власний розсуд одного з декількох варіантів рішень, кожне з яких $€$ правомірним [23]. Звідси випливає, що розробники намагалися зменшити навантаження на суддів та мінімізувати строк розгляду відповідного клопотання через те, що передача кримінального провадження, насамперед його таємної частини, слідчому судді значно б затягувала строк досудового розслідування, а в деяких випадках призводила б до не актуальності проведення певної НС(Р)Д та, як наслідок, втрати необхідних доказів протиправної діяльності особи (осіб). Однак такий підхід зумовлений інтересами сторони обвинувачення та необхідністю дотримання розумних строків під час проведення відповідних процесуальних дій [22, с. 36]. Наприклад, на момент звернення з клопотанням не завжди може бути відома конкретна інформація про особу (прізвище, ім'я, по батькові), стосовно якої планується проведення НС(Р)Д, що створює необхідність у такому разі слідчому (прокурору) у своєму клопотанні обгрунтувати причини ненадання відомостей, а слідчому судді перевірити і переконатися, що ці відомості є об'єктивними. Викладене, зокрема, зумовлене тим, що необхідність проведення НС(Р)Д може виникати до встановлення особи, підозрюваної у скоєнні злочину, за наявності обмежених даних і відсутності конкретних відомостей про таку особу [24, с. 31]. Із цього приводу О.I. Полюхович зазначає, що за буквальним змістом ч.3 статті 248 КПК предметом доказування під час розгляду слідчим суддею відповідного клопотання слідчого (прокурора) є доведення факту вчинення злочину відповідної тяжкості та продук- 
тивності використання НС(Р)Д як інструмента для отримання доказової інформації, а нормативним орієнтиром глибини дослідження суддею фактів та аргументів органів слідства $€$ категорія «достатність підстав», яка має оцінювальний характер [25, с. 175]. Однак питання про проведення НС(Р)Д є суб'єктивним питання для прокурора чи слідчого, адже саме ці особи вирішують чи є можливість зібрати докази завдяки гласним слідчим діям чи варто звертатися до негласних [26, с. 568].

Водночас цілком погоджуємося 3 думкою O.I. Полюховича, що ситуація ухвалення слідчим суддею рішення про дозвіл на проведення НС(Р)Д без ознайомлення з матеріалами кримінального провадження є свого роду нонсенсом, а тому у чинному КПК повинно бути закріплене положення про обов'язок слідчого надавати слідчому судді для ознайомлення матеріали кримінального провадження, якими підтверджується обгрунтованість клопотання про надання дозволу на проведення НС(Р)Д [27, с. 103-104]. Варто звернути увагу на практику Вищого антикорупційного суду, зокрема слідчі судді досліджують матеріали кримінальних проваджень, які стосуються обставин, зазначених у клопотанні про надання дозволу на проведення негласних слідчих (розшукових) дій. Так, наприклад, у 2020 році до слідчих суддів Вищого антикорупційного суду надійшло 2201 клопотань (1995 (90,5\%) - клопотання про надання дозволу на проведення НС(Р) Д, $206(9,5 \%)$ - про надання дозволу на проведення оперативно-розшукових заходів), з яких задоволено 1784 (81\%), задоволено частково 208 (9,5\%), відмовлено - 207 (9,5\%) [18]. Утім, не всі слідчі судді інших судів досліджують матеріали кримінальних проваджень. Наприклад, у звіті «Роль слідчого судді у кримінальному провадженні 2019-2020 роки» з 599 вивчених ухвал лише в 78 ухвалах (13\%) слідчі судді посилалися на докази обгрунтованості з їх аналізом, у 287 ухвалах $(48 \%)$ посилання на докази були, але без їх аналізу, а у 231 ухвалах $(38,5 \%)$ посилання на докази обгрунтованості взагалі не було [12, с. 155].

Влучно зазначає M.I. Шевчук щодо того, що суд не може бути стороннім спостерігачем за змаганням сторін, бездушним формалістом, який індиферентно ставиться до всебічного, повного та неупередженого з'ясування всіх обставин кримінального провадження, а отже, до встановлення істини, оскільки саме суд, а не прокурор чи захисник несе повну відповідальність за прийняте рішення (в тому числі і за неповноту судового розгляду, яка зумовлена пасивністю сторін у дослідженні доказів) [28, с. 135]. Така позиція слідчого судді не гарантує передбачені Конституцією України та міжнародними договорами захисту прав та законних інтересів для фізичних чи юридичних осіб, а кримінальне провадження не виконує тоді тих завдань, про які йдеться у статті 2 КПК України [4]. Для підтвердження цього слід навести статистичні дані офісу Генеральної прокуратури та судову статистику розгляду скарг на дії, рішення чи бездіяльність слідчого, прокурора та інших осіб під час досудового розслідування. Так, зокрема, впродовж 2020 року до слідчих суддів надійшло 159366 клопотань суб'єктів розслідування щодо проведення НСРД. За результатами розгляду клопотань судами задовільнено 147 888, відмовлено в задоволенні - 11478 [29]. Відповідно до звіту судів першої інстанції 
про розгляд матеріалів кримінального провадження № 1-к за 2020 рік із загальної кількості 105301 скарг, що надійшли до судів на дії, рішення чи бездіяльність слідчого, прокурора та інших осіб під час досудового розслідування 77113 скарг подано на бездіяльність слідчого чи прокурора, з яких задоволено 40070 скарг, а 2826 скарг стосувалися рішень слідчого, прокурора про відмову у задоволенні клопотання про проведення слідчий (розшукових) дій та НС(Р)Д, з яких 1063 задоволено [30].

До того ж ми погоджуємося з думкою С.Р. Тагієва, що під час здійснення судового контролю слідчим суддею важливим $є$ збільшення строку розгляду клопотань про проведення НС(Р)Д з 6 годин до 24 годин. Адже в більшості випадків слідчий суддя повинен мати фізичну можливість здійснити повноцінний аналіз поданих йому матеріалів та визначити необхідність застосування конкретної НСРД та конкретного технічного засобу, вивчити матеріали і встановити законність ініціювання НС(Р)Д, процесуальну необхідність проведення такого виду заходів, гарантії невтручання у приватне життя інших осіб, збалансованість обсягу проведення НСРД з урахуванням вчиненого і можливість використання інших доказів; впевненість у тому, що інформація буде отримана від конкретної особи [31, с. 152].

Висновок. Резюмуючи все вищесказане, потрібно зазначити, що слідчий суддя $є$ гарантом забезпечення законності та обгрунтованості обмеження конституційних прав і свобод людини під час проведення негласних слідчих (розшукових) дій, адже саме судовий контроль $є$ тим контролем, що захищає кожну особу від неправомірних дій і рішень суб'єктів владних повноважень, які обмежують конституційні права і свободи громадян під час проведення НС(Р)Д. Однак для забезпечення дієвого судового контролю за дотриманням прав і свобод особи під час проведення НС(Р)Д до чинного КПК України слід внести зміни, зокрема: закріпити положення про обов'язок слідчого чи прокурора надавати слідчому судді для ознайомлення матеріали кримінального провадження, якими підтверджується обгрунтованість клопотання про надання дозволу на проведення НС(Р) Д, здійснення судового контролю і за результатами проведення НС(Р)Д, збільшення строку розгляду клопотань із 6 годин до 24 годин.

\section{Література}

1. Загальна декларація прав людини : Міжнародний документ від 10 грудня 1948 р. База даних «Законодавство України». URL: https:/ / zakon.rada.gov.ua/laws/show/995_015\#Text

2. Конвенція про захист прав людини і основоположних свобод : Міжнародний документ від 04 квітня 1950 р. База даних «Законодавство України». URL: https: / / zakon.rada.gov.ua/ laws / show/995_004\#Text

3. Конституція України : Закон України від 28 червня 1996 р. № 254к / 96 / Верховна Рада України. URL: https: / / zakon.rada.gov.ua/laws/show /254\% D0\%BA/96-\% D0\% B2\% D1\% 80\#Text

4. Кримінальний процесуальний кодекс України : Закон України від 13 квітня 2012 р. № 4651VI / Верховна Рада України. URL: https:/ / zakon.rada.gov.ua/laws/show/4651-17\#Text

5. Нескоромний Д.А. Негласні слідчі (розшукові) дії: юридичні та фактичні підстави їх провадження. Науковий вісник Львівського державного університету внутрішніх справ. 2015. № 2. C. 303-312. URL: https://www.lvduvs.edu.ua/documents_pdf/visnyky/ nvsy/02_2015/15ndapyip.pdf

6. Дрозд В.Г. Судова практика щодо допустимості доказів, отриманих у результаті проведення негласних слідчих (розшукових) дій. Підприємництво, господарство і право. 2020. № 9. C. 185-190. DOI: https://doi.org/10.32849/2663-5313/2020.9.32 
7. Бондюк А.Ф. Процесуальні основи статусу слідчого судді у кримінальному провадженні : автореф. дис. ... канд. юрид. наук : 12.00.09. Київ, 2017. 20 с.

8. Гловюк І.В. Судовий контроль як категорія теорії судової діяльності у кримінальному процесі. Актуальні проблеми держави і права. 2009. Вип. 45. С. 367-371.

9. Волошина В.К. Судовий контроль як специфічний принцип досудового провадження. Актуальні проблеми держави і права. 2009. Вип. 47. С. 220-224.

10. Фаринник B.I. Застосування заходів забезпечення кримінального провадження: теорія та практика : монографія. Київ : Алерта, 2017. 548 с.

11. Марчак В.Я. Судовий контроль за дотриманням прав людини згідно з кримінальним процесуальним законодавством України. Юридичнй часопис Національної академії внутрішніх справ. 2013. № 1. С. 141-147.

12. Роль слідчого судді у кримінальному провадженні. 2019-2020 роки : Звіт за результатами дослідження / Автор. кол. : Ю.Л. Бєлоусов, В.М. Венгер, А.М. Ореан, Є.О. Крапивін, С.В. Шапутько, В.В. Яворська. Київ, 2020. 252 с. Відродження : вебсайт. URL: https: / / www.irf.ua/wp-content/uploads / 2020/05/rol_slsuddya_web-2.pdf?fbclid=iwar3r1_t9ii _8mumqkumorawbvapcrmyhihvfu3xrnnmoxfittz4ooyv7eli

13. Лисеюк А.М., Мулявка Д.Г., Гончарова А.О. Доказування на досудовому етапі кримінальних проваджень щодо злочинів у сфері незаконного обігу підакцизних товарів: проблеми теорії та практики : монографія. Київ : «Видавництво Людмила», 2019. 326 с.

14. Phenomenon of interference with private communication as the category of theory and practice of criminal proceedings / V. Teremetskyi, I. Tataryn, V. Kovalenko, M. Yakovenko, Zh. Udovenko, O. Salmanov. Journal of Legal, Ethical and Regulatory Issues. 2021. No. 24 (Special Issue 1). P. 1-9.

15. Організаційно-правові засади діяльності слідчих підрозділів Національної поліції України : монографія / В.Г. Дрозд, А.В. Пономаренко, С.Є. Абламський, Л.В. Гаврилюк та ін. ; Державний науково-дослідний інститут. Херсон : Видавничий дім «Гельветика», 2020. 352 с.

16. Попелюшко В.О. Слідчий суддя у кримінальному провадженні. Часопис Національного університету «Острозька академія». Серія: Право. 2014. № 1(9). C. 145-153. URL: http://www.irbis-nbuv.gov.ua/cgi-bin/irbis_nbuv/ cgiirbis_64.exe ?I21DBN=LINK\&P21DBN=UJRN \&Z21ID $=\& S 21 \mathrm{REF}=10 \& \mathrm{~S} 21 \mathrm{CNR}=20 \& \mathrm{~S} 21 \mathrm{STN}=1 \& \mathrm{~S} 21 \mathrm{FMT}=$ ASP_meta\&C21COM=S\&2_S21P03=FILA=\&2_S21STR=Choasp_2014_1_15

17. Лісовий О.О. Межі судового контролю під час проведення НС $(\bar{P})$ Д, пов'язаних із використанням технічних засобів. Юридичний електронний журнал. 2021. № 3. С. 323-327.

18. Узагальнення судової практики з розгляду слідчими суддями Вищого антикорупційного суду клопотань про надання дозволу на проведення негласних слідчих (розшукових) дій і оперативно-розшукових заходів (за 2019, 2020 роки) / Вищий антикорупційний суд. Київ, 2021. 41 c. URL: https://hcac.court.gov.ua/userfiles/media/new_folder_for_uploads/hcac/ statistics/reviews/review_CIA_OSM.pdf

19. Комарницька О.Б. Організаційні та процесуальні аспекти діяльності прокурора при погодженні клопотання на проведення негласних слідчих (розшукових) дій. Часопис Академіi адвокатури України. 2015. Т. 8. № 1. С. 17-26.

20. Мирошниченко Ю.М. Негласні слідчі (розшукові) дії: підстави проведення. Проблеми правоохоронної діяльності. 2019. № 2(23). С. 117-121.

21. Про затвердження Інструкції про організацію проведення негласних слідчих (розшукових) дій та використання їх результатів у кримінальному провадженні : Наказ Генеральної прокуратури України, Міністерства внутрішніх справ України, Служби безпеки України, Адміністрації державної прикордонної служби України, Міністерства фінансів України, Міністерства юстиції України від 16 листопада 2012 р. № 114/1042/516/1199/936/1687/5 / Генеральна прокуратура України, Міністерство внутрішніх справ України, Служба безпеки України, Адміністрація державної прикордонної служби України, Міністерство фінансів України, Міністерство юстиції України. URL: https:/ / zakon.rada.gov.ua/laws/show/v0114900-12\#Text

22. Соколов О.В. Виконання оперативними підрозділами доручень слідчого, прокурора про проведення негласних слідчих (розшукових) дій : дис. ... канд. юрид. наук : 12.00 .09 ; Національний юридичний університет імені Ярослава Мудрого. Харків, 2019. 240 с.

23. Про затвердження Методології проведення антикорупційної експертизи проєктів нормативно-правових актів : Наказ Міністерства юстиції України від 23 червня 2010 р. № 1380/5/ Міністерство юстиції України. URL: http:/ / zakon5.rada.gov.ua/laws/show/v1380323-10 
24. Відшкодування потерпілому шкоди, завданої кримінальним правопорушенням : методичні рекомендації / С.С. Чернявський та ін. Київ : Національна академія внутрішніх справ, 2016. 122 c.

25. Полюхович О.І. Проблемні питання судового розгляду клопотань про надання дозволу на проведення негласних слідчих (розшукових) дій. Науковий вісник Ужгородського національного університету. Серія «Право». 2016. Вип. 1. Т. 2. С. 172-176.

26. Левандаренко О.О., Іващенко Д.В. Негласні слідчі дії в контексті захисту конституційних прав і свобод учасників кримінального провадження. Форум права. 2012. № 4. С. 567-571. URL: http:/ / nbuv.gov.ua/ UJRN/FP_index.htm_2012_4_92

27. Полюхович O.I. Судовий контроль при проведенні негласних слідчих (розшукових) дій : дис. ... канд. юрид. наук : 12.00 .09 ; Національний юридичний університет імені Ярослава Мудрого. Харків, 2017. 231 с.

28. Шевчук М.І. Ініціатива суду та їі межі у з'ясуванні обставин кримінального провадження під час судового розгляду : дис. ... канд. юрид. наук : 12.00 .09 ; Львівський національний університет імені I. Франка. Львів, 2015. 244 с.

29. Звіт про роботу прокурорів за січень - грудень 2020 року. Портал відкритих даних : вебсайт. URL: https:/ / data.gov.ua/dataset/c150bc1b-54c0-4fd5-b7a6-d7e1df6acb34/resource/ bd043eb4-8d02-498e-9cd9-b2a10e0584e6

30. Звіт судів першої інстанції про розгляд матеріалів кримінального провадження № 1-к за 2020 рік. Судова влада України : вебсайт. URL: https://court.gov.ua/inshe/ sudova_statystyka / rik_2020

31. Тагієв С.Р. Процесуальні дії слідчого судді при наданні дозволу на проведення негласних слідчих (розшукових) дій. Слово Нащіональної школи суддів України. 2013. № 4. С. 145-155.

\section{А н о т а ці я}

Дроздова О. В., Заріцька $K . Г$. Слідчий суддя як гарант забезпечення законності та обрунтованості обмеження конституційних прав і свобод людини під час проведення негласних слідчих (розшукових) дій. - Стаття.

У статті розглянуто поняття «судовий контроль за дотриманням прав людини під час проведення негласних слідчих (розшукових) дій», ознаки й особливості здійснення слідчим суддею такого контролю під час проведення негласних слідчих (розшукових) дій.

Акцентовано на тому, що судовий контроль за дотриманням прав людини під час проведення негласних слідчих (розшукових) дій здійснюється з метою перевірки правомірності застосування до осіб заходів процесуального примусу, які обмежують конституційний принцип недоторканності особи, а також запобігання неправомірним діям і рішенням, що порушують конституційні права й свободи громадян.

Виділено основні проблеми правового регулювання судового контролю слідчих суддів під час проведення негласних слідчих (розшукових) дій, до яких віднесено: невизначеність чіткого розуміння в нормах кримінального процесуального закону статусу втручання в приватне спілкування в системі негласних слідчих (розшукових) дій як самостійної негласної слідчої (розшукової) дії, яка може проводитись у визначених законом різновидах, чи узагальнюючого поняття, що містить у собі чотири самостійні негласні слідчі (розшукові) діï, визначені нормами Кримінального процесуального кодексу України як різновиди втручання в приватне спілкування; невизначеність і відсутність чітких меж судового контролю; невизначеність правового статусу й повноважень слідчого судді; невизначеність і відсутність чіткого порядку відбору кандидатів на виконання судово-контрольної функції.

Зроблено висновок, що для забезпечення дієвого судового контролю за дотриманням прав і свобод особи під час проведення негласних слідчих (розшукових) дій до чинного Кримінального процесуального кодексу України слід внести зміни, зокрема закріпити положення про обов'язок слідчого чи прокурора надавати слідчому судді для ознайомлення матеріали кримінального провадження, якими підтверджується обгрунтованість клопотання про надання дозволу на проведення негласних слідчих (розшукових) дій, здійснення судового контролю та за результатами проведення негласних слідчих (розшукових) дій, збільшення строку розгляду клопотань із 6 годин до 24 годин.

Ключові слова: кримінальне провадження, досудове розслідування, слідчий суддя, негласні слідчі (розшукові) дії, законність, обмеження прав і свобод людини. 
Drozdova $O . V$. , Zaritska $K$. G. Investigating judge as a guarantor of ensuring the legality and justification of restrictions on constitutional human rights and freedoms during covert investigative (search) actions (CISA). - Article.

The article considers the concept of judicial control over the observance of human rights during the CISA the signs and features of the investigative judge's exercise of such control during the CISA.

Emphasis is placed on the fact that judicial control over the observance of human rights during the CISA is carried out in order to verify the legality of coercive measures that limit the constitutional principle of inviolability, as well as to prevent illegal actions and decisions that violate constitutional rights and freedoms of citizens.

The main problems of legal regulation of judicial control of investigative judges during the CISA are highlighted, which include: the ambiguity of clear understanding in the norms of the criminal procedural law of the status of the interference with private communication within the system of CISA: as an independent CISA, which can be carried out in the statutory varieties, or a general concept containing four independent CISAs defined by the norms of the Criminal Procedural Code of Ukraine of Ukraine as types of the interference with private communication, uncertainty and lack of clear boundaries of judicial control, the uncertainty of legal status and powers of the investigator judges, uncertainty and lack of a clear procedure for selecting candidates for judicial control. It is concluded that in order to ensure effective judicial control over the observance of individual rights and freedoms during the CISA, the current the Criminal Procedural Code of Ukraine should be amended, in particular: to establish provisions on the duty of investigators or prosecutors to provide, which confirms the validity of the request for permission to conduct of CISA, judicial review and the results of the CISA, increasing the period of consideration of applications from 6 hours to 24 hours.

Key words: criminal proceedings, pre-trial investigation, investigative judge, covert investigative (search) actions, legality, restriction of human rights and freedoms. 